\title{
Engineered nanomaterials as fighters against SARS-CoV-2: The way to control and treat pandemics
}

\author{
Mohamed Abd Elkodous $^{1,2}$ (1) $\cdot$ Gharieb S. El-Sayyad ${ }^{3,4}$ (D) Mohamed M. Abdel-Daim $^{5,6}$ (D)
}

Received: 18 May 2020 / Accepted: 28 September 2020 / Published online: 17 October 2020

(C) Springer-Verlag GmbH Germany, part of Springer Nature 2020

\begin{abstract}
In this editorial trend, we aim to collect and present recently available data about the characteristics of SARS-CoV-2 virus, severity, infection, replication, diagnosis, and current medications. In addition, we propose the role of nanomaterials in controlling and treating COVID-19 through their antiviral and antibacterial potential with suggested action mechanisms indicating the capability of interaction between these nanomaterials and SARS-CoV-2. These nanomaterials might be among the possible and most effective cures against coronavirus.
\end{abstract}

Keywords Corona viruses $\cdot$ Nanomaterials $\cdot$ COVID-19 $\cdot$ Nano-vaccines $\cdot$ Nanodrugs

\section{Introduction}

COVID-19 is caused by severe acute respiratory syndrome coronavirus 2 (SARS-CoV-2), a lethal beta-type virus belonging to a related group of viruses known as coronaviruses, leading to serious infections in the respiratory tract of humans (Fan et al. 2019; Sivakumar 2020; Yang and Wang 2020). Many human coronaviruses have been discovered such as SARS-CoV, $\mathrm{HCoV}$ NL63, HKU1, MERS-CoV, and SARS-CoV-2 causing COVID-19 disease (Su et al. 2016; Zhu et al. 2020). The name of coronaviruses was derived from Latin corona meaning crown, the name corresponds to their unique morphology due to the presence of viral spike proteins (Chafekar 2012; Lopez 2007).

Responsible Editor: Philippe Garrigues

Mohamed Abd Elkodous

mohamed.hamada.abdlekodous.xi@tut.jp

$\triangle$ Gharieb S. El-Sayyad

Gharieb.Elsayyad@eaea.org.eg

$\triangle$ Mohamed M. Abdel-Daim

abdeldaim.m@vet.suez.edu.eg

1 Department of Electrical and Electronic Information Engineering, Toyohashi University of Technology, Toyohashi, Aichi 441-8580, Japan

2 Center for Nanotechnology (CNT), School of Engineering and Applied Sciences, Nile University, Sheikh Zayed, Giza 16453, Egypt
Coronaviruses have large spherical structures with an average diameter of $120 \mathrm{~nm}$, and they have a lipid bilayer envelope of about $80 \mathrm{~nm}$ and $20 \mathrm{~nm}$ long spikes (Buzon et al. 2011; Fehr and Perlman 2015; Goldsmith et al. 2004; Yang and Wang 2020). The members of beta-coronavirus possess additional short-like protein called hemagglutinin esterase (HE) on their surfaces (Fehr and Perlman 2015). Interestingly, the structural proteins of the membrane, envelope, and the spike are anchored. In December 2019, COVID-19 emerged for the first time in China and has quickly-transmitted in the world (Angel-Korman et al. 2020). Recently, COVID-19 pandemic outbreak was recently-declared by the World Health Organization (WHO) (Angel-Korman et al. 2020).

3 Drug Radiation Research Department, National Center for Radiation Research and Technology (NCRRT), Egyptian Atomic Energy Authority (EAEA), Nasr City, Cairo, Egypt

4 Chemical Engineering Department, Military Technical College (MTC), Egyptian Armed Forces, Cairo, Egypt

5 Department of Zoology, College of Science, King Saud University, P.O. Box 2455, Riyadh 11451, Saudi Arabia

6 Pharmacology Department, Faculty of Veterinary Medicine, Suez Canal university, Ismailia 41522, Egypt 


\section{Severity of COVID-19}

Unlike SARS-CoV, COVID-19 transmission takes place during the prodromal period when the infected persons are mildly ill and carrying on with their common activities, facilitating spread of infection (Liu et al. 2020). Direct contact with infected individuals and sneezing or coughing (droplets spread) are the main causes of person-to-person transmission (Chan et al. 2020; Thompson 2020). According to WHO, individuals at risk include elderly ( $>60$ years old); cardiac, diabetic, chronic respiratory, cancer patients, and individuals in longterm care facilities (Kabir et al. 2020).

\section{SARS-CoV-2 infection and replication}

The virus relies on the ACE2 receptor not only for host cell entry but also for subsequent viral replication (Zhang et al. 2020b). High viral loads have been observed in the lower respiratory tract, proposing that the virus might have a higher affinity for the epithelium of the lower respiratory tract and indicating a need for repeat testing of the upper or lower respiratory tract samples in the setting of an initial negative result of nasopharyngeal or throat swab in a suspected case (Jansen et al. 2011; McCulloh et al. 2013; Rai et al. 2020). ACE2 receptors' presence in the extrapulmonary tissues (heart, kidney, endothelium, and intestine) could also explain the multiorgan dysfunction observed in patients (Zhang et al. 2020a). SARS-CoV-2 is known to cause a delayed type I interferon response during the initial phases of infection (Frieman and Baric 2008). Infection and viral replication lead to activation of neutrophils, macrophages, and monocytes (Nikitina et al. 2018). Th1/Th17-induced specific antibodies are produced (Mitsdoerffer et al. 2010). RNA viruses such as SARS-CoV and MERS are recognized pathogen associated molecular patterns by endosomal RNA receptors, TLR7 and TLR3, and the cytosolic RNA sensor, RIG-I/MDA5 (Kell and Gale Jr 2015; Poeck et al. 2010; Takeuchi and Akira 2008).

\section{Diagnosis of COVID-19}

WHO has published diagnostic criteria that help identify patients requiring confirmation of COVID-19 through either PCR or antibody detection tests (Vos et al. 2019). These criteria include several epidemiological and clinical criteria that the patient has to fulfill in order to be either COVID-19 suspected or confirmed case (https://www.cdc.gov/ coronavirus/2019-ncov/community/correction-detention/ guidance-correctional-detention.html). History of patients infected with coronavirus disease 2019 (COVID-19) can include international travel to where COVID-19 is highly-prevalent. Fever, fatigue, cough, and breath shortness are the most common symptoms that can appear 2-14 days after exposure (Cascella et al. 2020).

Coronaviruses-derived illness can be investigated through many laboratory tests. Specific laboratory tests include serology for viral antigen, molecular testing, and viral culture (Kabir et al. 2020; Storch 2000). All these tests can be used to confirm infection with coronavirus. Non-specific laboratory findings in COVID-19 include lymphocytopenia, thrombocytopenia, elevated CRP, elevated ALT, AST, creatine kinase, D-dimer, and markers of cell damage, e.g., troponin, lactate dehydrogenase, interleukin-4, and procalcitonin (Lippi and Plebani 2020).

The chest $\mathrm{x}$-ray remarks of a suspected coronavirus case can be similar to pneumonia (Jacobi et al. 2020). Severe cases of COVID-19 progressing to acute respiratory distress syndrome (ARDS) can show a typical "white-out" on chest $\mathrm{x}$ ray (Venugopal et al. 2020). There are no specific echocardiography/ultrasound findings associated with coronavirus infection (Zheng et al. 2020). Non-specific echocardiographic findings can include left ventricular systolic dysfunction and pericardial effusion (Pérez-Casares et al. 2017). Chest $\mathrm{CT}$ scan findings in patients infected with coronavirus can include unilateral or bilateral pneumonia, mottling and ground glass opacity, focal or multifocal opacities, consolidation, and septal thickening with sub-pleural and lower lobe involvement more likely (Wu et al. 2020).

\section{COVID-19 current medications}

Treatment of coronavirus infection includes supportive measures and symptomatic management. No specific treatment is available. Given the emergence of the cases during the influenza season, all patients presenting with COVID-19 were given oral and intravenous antibiotics and oseltamivir (75 $\mathrm{mg}$ twice daily via oral route) empirically (Control and Prevention 2014).

Corticosteroids (methyl prednisolone $40-120 \mathrm{mg} /$ day) were given as a combined regimen if severe communityacquired pneumonia was diagnosed (Chen et al. 2011). Oxygen support (e.g., via nasal cannula and invasive mechanical ventilation) was given to patients indicated by the severity of hypoxemia (Curley et al. 2015). Surgery is not indicated in the management of COVID-19. Investigational therapies include hydroxychloroquine alone or in combination with azithromycin, remdesivir, and lopinavir/ritonavir. Currently, avoiding virus exposure is the best way to prevent the infection (Organization 2020).

\section{Nanomaterials as promising nano-vaccines and nano-drug}

Nanotechnology through a large variety of nanomaterials (NMs) possessing multiple structures, properties, and 


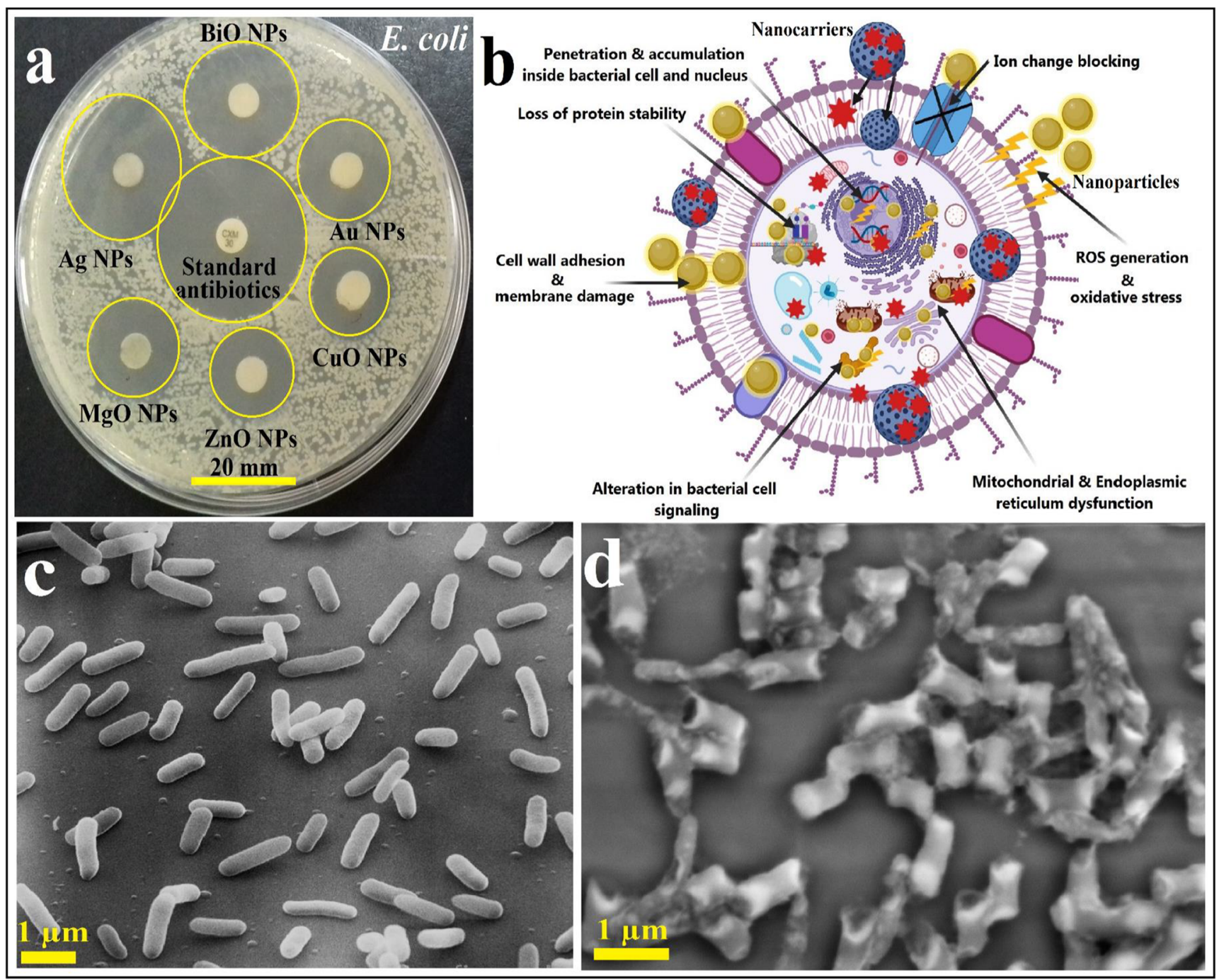

Fig. 1 Antimicrobial potential of different synthesized NPs where (a) measuring the activity of different NPs by zone of inhibition (ZOI) method against $E$. coli bacterial cells, (b) suggested reaction mechanism of some nanoparticles (Ag and Au NPs) and drugs nanocarriers against bacterial cells ((I): NPs are firstly-interact with the external part of the pathogenic bacteria and change their membrane composition, and then they easily-enter bacterial cells because of their small nano-size; (II) NPs are quickly-diffused across bacterial cells and interacted with the main bacterial organelles and bio-molecules and increased cellular toxicity, loss of protein stability, and finally genotoxicity; (III) NPs generated active ROS inside bacterial cells and initiated bacterial cell disruption; and (VI) NPs have alternated the cellular sign system causing cell disorder. Also, NPs might serve as a vehicle to deliver their ions to the bacterial cytoplasm leading to a reduction in the proton motive force (PMF) which might decrease the bacterial cell $\mathrm{pH}$ to less than 3.5 , and promoting the liberations of their ions), (c) normal $E$. coli growth without the effect of any synthesized NPs which appears as normal cell with a rigid cell wall and high cell count, and (d) malformed and distorted bacterial cell (E. coli) following the treatment of NPs suggesting the usage of NPs in fighting the secondary bacterial infection associated with viral diseases characteristics can offer a revolutionary solution for the control and treatment of this disease. Many types of NMs showed very promising antiviral and antimicrobial activities which could be used as nano-vaccines to prevent microbial biofilm formation and the adsorption of microbes onto the surfaces and to control their transmission as shown in Fig. 1 (Abd Elkodous et al. 2019a, b; 2020; Chen and Liang 2020; ElSayyad et al. 2020; Kim et al. 2020; Mohamed et al. 2020; Tran et al. 2020; Wong et al. 2020).

The antimicrobial activity results of some green synthesized metal NPs (such as Ag NPs, and Au NPs) should be considered. The biogenic Au NPs mostly-displayed mild antibacterial activities against the highly-pathogenic bacteria (Aina et al. 2019; Elegbede et al. 2020). Sunday A. Ojo et al. (Ojo et al. 2016) investigated the antimicrobial potential of the green synthesized Au and Ag-Au alloy NPs, and the results indicated that they displayed growth inhibitions of 66.67-90.78\% against strains of Aspergillus fumigatus and Aspergillus niger at a concentration of $200 \mu \mathrm{g} / \mathrm{ml}$. In addition, $\mathrm{Ag}-\mathrm{Au}$ NPs exhibited tremendous antifungal activities. An interesting result of nearly $100 \%$ inhibition of A. flavus growth after the treatment with $\mathrm{Ag}-\mathrm{Au}$ NPs at a concentration of 
$150 \mu \mathrm{g} / \mathrm{ml}$ was reported (Lateef et al. 2016). The strong antifungal potential of Ag-Au NPs can be attributed to the adhesion on the microbial cell wall, subsequent suppression of fungal spores, then cytoplasmic content leakage, and finally microbial cell death (Elegbede et al. 2019).

The antimicrobial characteristics of some nanomaterials depend on their size, shape, surface features, and surface charge. As a result, their toxicological effects are controllable by the employed concentration (Sportelli et al. 2020). The toxic levels of NPs must be taken into consideration before designing any nano-drug, and the antimicrobial minimum inhibitory concentration (MIC) should be measured (Abdel Maksoud et al. 2020; El-Batal et al. 2020).

Many studies focusing on reaction mechanisms and cytotoxicity are needed before the development of reliable nanovaccines and nano-drug (Abd Ellah et al. 2020).

Immune system-stimulating nano-vaccines could be easily-assembled through either encapsulation of viral parts within NMs or via decoration (covalent functionalization) on the surface of many suitable NMs such as virus-like nanoparticles (NPs), solid-lipid NPs, liposome-based NPs, and biodegradable polymer-based NPs (Dhakal and Renukaradhya 2019; Xu et al. 2020).

In addition, many types of $\mathrm{NMs}$ such as $\mathrm{TiO}_{2} \mathrm{NPs}, \mathrm{ZnO}$ $\mathrm{NPs}$, and $\mathrm{Cu}$ NPs with very small concentrations could be employed to control the disease via surfaces' coating and disinfection at hospitals and public places (Akinola et al. 2020; $\mathrm{Xu}$ et al. 2020). Moreover, self-assembled protein NPs obtained through recombinant technologies are considered on the most promising nano-vaccines against respiratory viruses (Scheerlinck and Greenwood 2008; Schneider-Ohrum and Ross 2012).

Christopher M. Coleman et al. reported a unique nanovaccine based on lipid nanoparticles carrying SARS-CoV and MERS-CoV spike proteins without any viral proteins which effectively-induced antibody responses in mice (Coleman et al.

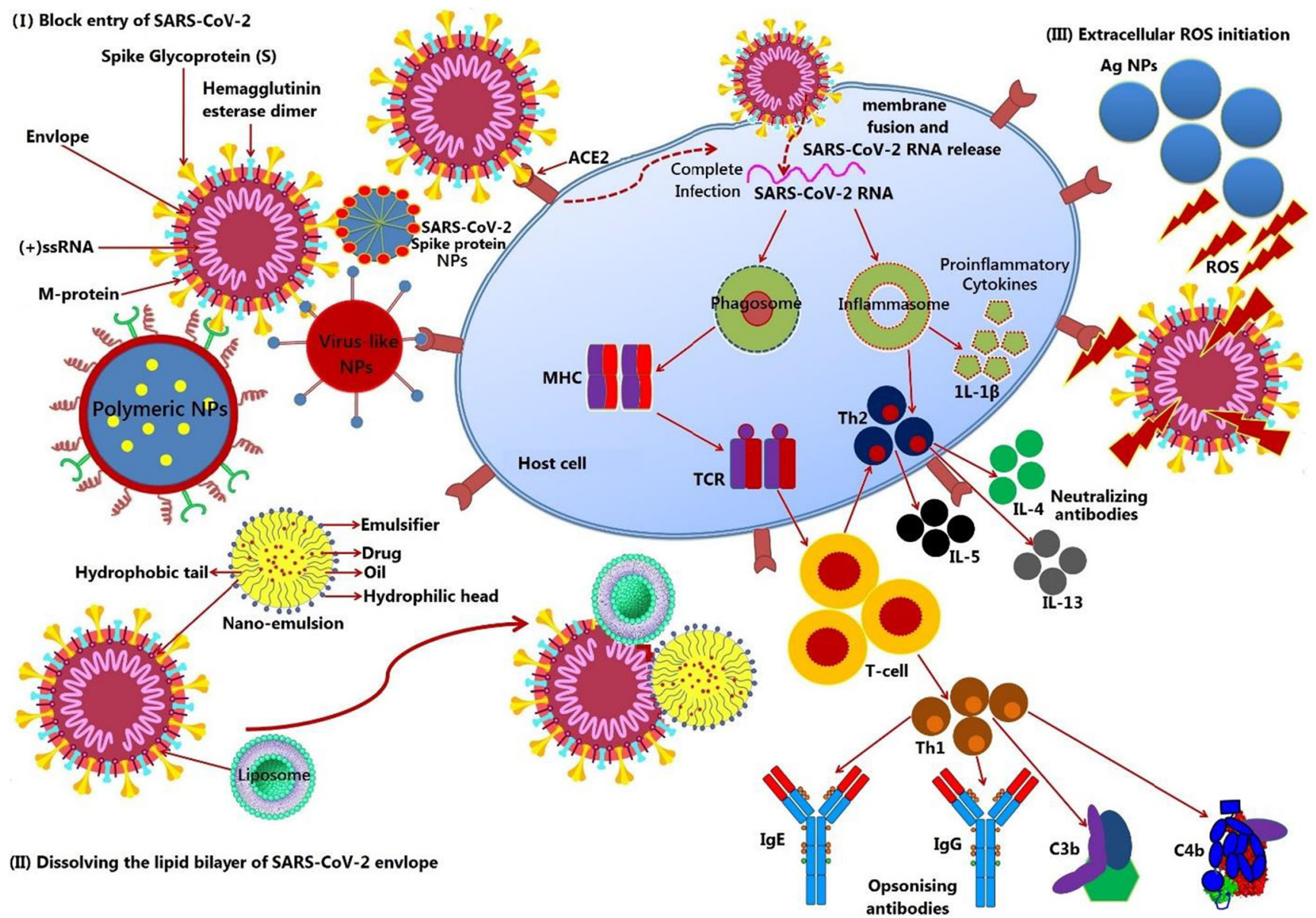

Fig. 2 Proposed reaction mechanisms of various engineered NMs against SARS-CoV-2, action mechanisms outside host cell (I) blocking of virus entry through either binding with the virus spike protein or blocking its cell receptor (ACE2) by virus-like NPs, polymeric NPs, and SARS-CoV2 spike protein NPs (has not been prepared yet); (II) dissolving the lipid bilayer of SARS-CoV-2 envelope by nano-emulsion, liposomes, and solid-lipid NPs; and (III) initiation of extracellular ROS by Ag NPs.
Actions inside host cell include activation of transcription factors by receptor signaling as a response of viral RNA and either the formation of pro-inflammatory cytokines (IL-1B) and activation of Th2 pathway ending with the formation of neutralizing antibodies (IL-4, IL-5, and IL-13) or Th1 pathway activation and the formation of opsonizing antibodies (IgE, C4b, C3b, and $\mathrm{IgG}$ ) 
2014). Similarly, Hyo-Jung Park et al. developed two MERS$\mathrm{CoV}$ vaccines from spike nanoparticles and spike proteinexpressing recombinant adenovirus 5 (Park et al. 2017). Both vaccines triggered immune responses of Th1 and Th2.

Choi et al. (2017) reported another nano-vaccine for MERS-CoV in mice; the vaccine was developed from human Fc4-fused eS1-770 spike protein of the virus. After 10 days, they discovered large quantity of antibodies against MERS$\mathrm{CoV}$, while $\mathrm{Ye} \mathrm{V}$. Liu et al. tested vaccines based on virus-like particles (VLPs) similar in morphology and size to the wild SARS-CoV, comprising SARS spike protein conjugated with influenza M1 protein (Liu et al. 2011). Upon treatment, mice protection from death, reducing the lung infection and antibodies against the virus, were achieved.

Another study which showed the great promise of zirconia $\left(\mathrm{ZrO}_{2}\right) \mathrm{NPs}$ as antiviral candidates against $\mathrm{H} 5 \mathrm{~N} 1$ pathogenic influenza virus in mice was reported by Huo et al. (Huo et al. 2020). Their results revealed that $\mathrm{ZrO}_{2} \mathrm{NPs}$ treatment resulted in a reduction in the virus replication, pro-inflammatory cytokines' over expression, and less lung injury.

\section{Reaction mechanisms of NMs against SARS-CoV-2}

Indeed, NMs can be employed as either nano-vaccines to prevent viral infection and to control its spread or as nano-drugs for the treatment (Panda et al. 2020). Nano-vaccines are more effective than traditional vaccines because they are capable of stimulating the immune response (cell-mediated and humoral) of the body to form antibodies and to prevent it from spreading by blocking its entry to the host cell (Sekhon and Saluja 2011). In addition, nano-drugs can be used as nasal drops and can achieve effective targeting of a particular antigen for more effective treatment (Mehrabi et al. 2020).

The action mechanisms start when the NMs react with the virus through hydrogen bonding interactions and electrostatic attractions or when NMs enter the host cell through transient pores in its cell membrane to fight the virus inside (Verma et al. 2008).

The proposed action mechanisms of nano-vaccines and nano-drugs against SARS-CoV-2 can be classified into two categories, the action before virus entering to the host cell (nano-vaccines) and after entering it (nano-drugs). Firstly, several types of nano-vaccines such as virus-like NPs and polymeric NPs can effectively-block virus entry through blocking ACE2 cell receptor or virus spike protein through which it enters the host cell through endocytosis mediated by clathrin (Zhou et al. 2020).

SARS-CoV-2 spike protein-loaded NPs can be prepared to either block virus entry or activate the immune system to form antibodies against the virus. In addition, liposomes and nanoemulsion can dissolve the lipid bilayer envelope of the virus and destroy its structure, and inorganic NPs (Ag NPs) can effectively-initiate extracellular reactive-oxygen species (ROS) to kill the virus (El-Batal et al. 2018).

Secondly, after virus entry to the host cell, NMs can stimulate ROS and enhance lymphocyte proliferation, over expression of cytokines, and the formation of either neutralizing antibodies of opsonizing antibodies through Th1 or Th2 immune responses as shown in Fig. 2.

In addition, NPs such as $\mathrm{TiO}_{2}, \mathrm{Ag}$, and $\mathrm{Au}$ can reduce the risk of high mortality among patients with COVID-19 due to hyperactivity of blood platelets which can lead to the formation of deadly blood clots (Akinola et al. 2020; Ojo et al. 2016). Moreover, serious complications such as heart attacks and strokes can be also suppressed (Elegbede et al. 2020). Coagulation of blood through lysis of blood clots can significantly-reduce the severity of COVID-19.

\section{Conclusion}

In this editorial trend, we covered most known data about coronavirus, properties, family identification, its severity, method of infection, and replication. In addition, we discussed its diagnosis and highlighted the currently-available medications to deal with its driven symptoms and effects. Finally, we proposed multiple nanomaterials that can be used as fighters against this disease, and we have classified them according to the mode of action into nano-vaccines and nano-drugs and revealed the way by which they can resist the virus. However, intensive efforts should be devoted for investigating the efficiency of these nanomaterials against viral samples as a step towards cure development. Importantly, with this high rate of dissemination of viruses and the frustrating slow drug development, there is an urgent need for developing new nanomedicines of high quality, safety, and availability to all countries at a reasonable cost.

Acknowledgments All figures in this editorial trend were created with BioRender.com.

Authors' contributions (MAE, and GSE manuscript writing, draw figures and revision. MMA conducted manuscript moderation and revision).

\section{Compliance with ethical standards}

Conflict of interest The authors declare that they have no conflict of interest.

Ethical approval Not required.

\section{References}

Abd Elkodous M, El-Sayyad GS, Abdelrahman IY, El-Bastawisy HS, Mohamed AE, Mosallam FM, Nasser HA, Gobara M, Baraka A, 
Elsayed MA, El-Batal AI (2019a) Therapeutic and diagnostic potential of nanomaterials for enhanced biomedical applications. Colloids Surf B: Biointerfaces 180:411-428

Abd Elkodous M, El-Sayyad GS, Nasser HA, Elshamy AA, Morsi M, Abdelrahman IY, Kodous AS, Mosallam FM, Gobara M, El-Batal AI (2019b) Engineered nanomaterials as potential candidates for HIV treatment: between opportunities and challenges. J Clust Sci 30:531-540

Abd Elkodous M, El-Sayyad GS, Abdel Maksoud MIA, Abdelrahman IY, Mosallam FM, Gobara M, El-Batal AI (2020) Fabrication of ultra-pure anisotropic zinc oxide nanoparticles via simple and costeffective route: implications for UTI and EAC medications. Biol Trace Elem Res 196:297-317

Abd Ellah NH, Gad SF, Muhammad K, Batiha GE, Hetta HF (2020) Nanomedicine as a promising approach for diagnosis, treatment and prophylaxis against COVID-19. Nanomedicine 15:2085-2102

Abdel Maksoud MIA, El-Sayyad GS, El-Khawaga AM, Abd Elkodous M, Abokhadra A, Elsayed MA, Gobara M, Soliman LI, ElBahnasawy HH, Ashour AH (2020) Nanostructured Mg substituted $\mathrm{Mn}-\mathrm{Zn}$ ferrites: A magnetic recyclable catalyst for outstanding photocatalytic and antimicrobial potentials. J Hazard Mater 399:123000

Aina DA, Owolo O, Lateef A, Aina FO, Hakeem AS, Adeoye-Isijola M, Okon V, Asafa TB, Elegbede JA, Olukanni OD (2019) Biomedical applications of Chasmanthera dependens stem extract mediated silver nanoparticles as antimicrobial, antioxidant, anticoagulant, thrombolytic, and larvicidal agents. Kar Inter J Mod Sci 5:2

Akinola P, Lateef A, Asafa T, Beukes L, Hakeem A, Irshad H (2020) Multifunctional titanium dioxide nanoparticles biofabricated via phytosynthetic route using extracts of Cola nitida: antimicrobial, dye degradation, antioxidant and anticoagulant activities. Heliyon 6:e4610

Angel-Korman A, Brosh T, Glick K, Leiba A (2020) COVID-19, the kidney and hypertension. Harefuah 159:231-234

Buzon MJ, Seiss K, Weiss R, Brass AL, Rosenberg ES, Pereyra F, Xu GY, Lichterfeld M (2011) Inhibition of HIV-1 integration in ex vivo-infected CD4 T cells from elite controllers. J Virol 85:96469650

Cascella M, Rajnik M, Cuomo A, Dulebohn SC, Di Napoli R (2020) Features, evaluation and treatment coronavirus (COVID-19), StatPearls [Internet]. StatPearls Publishing

Chafekar A (2012) Production of cytokines in human whole blood after incubation with the nucleocapsid protein of the NL63 coronavirus

Chan JF-W, Yuan S, Kok K-H, Tos KK-W, Chu H, Yang J, Xing F, Liu J, Yip CC-Y, Poon RW-S (2020) A familial cluster of pneumonia associated with the 2019 novel coronavirus indicating person-toperson transmission: a study of a family cluster. Lancet 395:514 523

Chen L, Liang J (2020) An overview of functional nanoparticles as novel emerging antiviral therapeutic agents. Mater Sci Eng C 110924

Chen Y, Li K, Pu H, Wu T (2011) Corticosteroids for pneumonia. Cochrane database of systematic reviews, Corticosteroids for pneumonia

Choi J, Kim M-G, Oh Y-K, Kim YB (2017) Progress of Middle East respiratory syndrome coronavirus vaccines: a patent review. Expert Opin Ther Pat 27(6):721-731. https://doi.org/10.1080/13543776. 2017.1281248

Coleman CM, Liu YV, Mu H, Taylor JK, Massare M, Flyer DC, Glenn GM, Smith GE, Frieman MB (2014) Purified coronavirus spike protein nanoparticles induce coronavirus neutralizing antibodies in mice. Vaccine 32:3169-3174

Control CfD, Prevention (2014) Influenza antiviral medications: summary for clinicians

Curley GF, Laffy JG, Zhang H, Slutsky AS (2015) Noninvasive respiratory support for acute respiratory failure - high flow nasal cannula oxygen or non-invasive ventilation? J Thorac Dis 7:1092
Dhakal S, Renukaradhya GJ (2019) Nanoparticle-based vaccine development and evaluation against viral infections in pigs. Vet Res 50:90

El-Batal AI, Mosallam FM, El-Sayyad GS (2018) Synthesis of metallic silver nanoparticles by fluconazole drug and gamma rays to inhibit the growth of multidrug-resistant microbes. J Clust Sci 29:10031015

El-Batal AI, Nada HG, El-Behery RR, Gobara M, El-Sayyad GS (2020) Nystatin-mediated bismuth oxide nano-drug synthesis using gamma rays for increasing the antimicrobial and antibiofilm activities against some pathogenic bacteria and Candida species. RSC Adv 10:9274-9289

Elegbede JA, Lateef A, Azeez MA, Asafa TB, Yekeen TA, Oladipo IC, Hakeem AS, Beukes LS, Gueguim-Kana EB (2019) Silver-gold alloy nanoparticles biofabricated by fungal xylanases exhibited potent biomedical and catalytic activities. Biotechnol Prog 35:e2829

Elegbede JA, Lateef A, Azeez MA, Asafa TB, Yekeen TA, Oladipo IC, Aina DA, Beukes LS, Gueguim-Kana EB (2020) Biofabrication of gold nanoparticles using xylanases through valorization of corncob by Aspergillus niger and Trichoderma longibrachiatum: antimicrobial, antioxidant, anticoagulant and thrombolytic activities. Waste Biomass Valori 11:781-791

El-Sayyad GS, Abd Elkodous M, El-Khawaga AM, Elsayed MA, ElBatal AI, Gobara M (2020) Merits of photocatalytic and antimicrobial applications of gamma-irradiated $\mathrm{Co}_{\mathrm{x}} \mathrm{Ni}_{1-\mathrm{x}} \mathrm{Fe}_{2} \mathrm{O}_{4} / \mathrm{SiO}_{2} / \mathrm{TiO}_{2}$; $=0.9$ nanocomposite for pyridine removal and pathogenic bacteria/ fungi disinfection: implication for wastewater treatment. RSC Adv 10:5241-5259

Fan Y, Zhao K, Shi Z, Zhou P (2019) Bat coronaviruses in China. Viruses $11: 210$

Fehr AR, Perlman S (2015) Coronaviruses: an overview of their replication and pathogenesis, coronaviruses. Springer, pp 1-23

Frieman M, Baric R (2008) Mechanisms of severe acute respiratory syndrome pathogenesis and innate immunomodulation. Microbiol Mol Biol Rev 72:672-685

Goldsmith CS, Tatti KM, Ksiazek TG, Rollin PE, Comer JA, Lee WW, Rota PA, Bankamp B, Bellini WJ, Zaki SR (2004) Ultrastructural characterization of SARS coronavirus. Emerg Infect Dis 10:320

Huo C, Xiao J, Xiao K, Zou S, Wang M, Qi P, Liu T, Hu Y (2020) Pretreatment with zirconia nanoparticles reduces inflammation induced by the pathogenic H5N1 influenza virus. Int J Nanomedicine 15: 661-674

Jacobi A, Chung M, Bernheim A, Eber C (2020) Portable chest X-ray in coronavirus disease-19 (COVID-19): a pictorial review. Clin Imaging 64:35-42

Jansen RR, Wieringa J, Koekkoek SM, Visser CE, Pajkrt D, Molenkamp R, de Jong MD, Schinkel J (2011) Frequent detection of respiratory viruses without symptoms: toward defining clinically relevant cutoff values. J Clin Microbiol 49:2631-2636

Kabir MT, Uddin MS, Hossain MF, Abdulhakim JA, Alam MA, Ashraf GM, Bungau SG, Bin-Jumah MN, Abdel-Daim MM, Aleya L (2020) nCOVID-19 pandemic: from molecular pathogenesis to potential investigational therapeutics. Front Cell Dev Biol 8:616

Kell AM, Gale M Jr (2015) RIG-I in RNA virus recognition. Virology 479:110-121

Kim J, Yeom M, Lee T, Kim H-O, Na W, Kang A, Lim J-W, Park G, Park C, Song D (2020) Porous gold nanoparticles for attenuating infectivity of influenza a virus. J Nanobiotechnology 18:1-11

Lateef A, Ojo SA, Folarin BI, Gueguim-Kana EB, Beukes LS (2016) Kolanut (Cola nitida) mediated synthesis of silver-gold alloy nanoparticles: antifungal, catalytic, larvicidal and thrombolytic applications. J Clust Sci 27:1561-1577

Lippi G, Plebani M (2020) Laboratory abnormalities in patients with COVID-2019 infection. 20200198

Liu YV, Massare MJ, Barnard DL, Kort T, Nathan M, Wang L, Smith G (2011) Chimeric severe acute respiratory syndrome coronavirus (SARS-CoV) S glycoprotein and influenza matrix 1 efficiently form 
virus-like particles (VLPs) that protect mice against challenge with SARS-CoV. Vaccine 29:6606-6613

Liu J, Liao X, Qian S, Yuan J, Wang F, Liu Y, Wang Z, Wang F, Liu L, Zhang Z (2020) Community transmission of severe acute respiratory syndrome coronavirus 2, Shenzhen, China, 2020. Emerg Infect Dis 26

Lopez LA (2007) Coronavirus envelope proteins: roles in subcellular trafficking and virus assembly. Arizona State University

McCulloh RJ, Koster M, Chapin K (2013) Respiratory viral testing: new frontiers in diagnostics and implications for antimicrobial stewardship. Virulence 4:1-2

Mehrabi M, Dounighi NM, Mohammadi M, Masoudi A (2020) Nanoparticles and vaccine development. Pharm Nanotechnol 8:621

Mitsdoerffer M, Lee Y, Jäger A, Kim H-J, Korn T, Kolls JK, Cantor H, Bettelli E, Kuchroo VK (2010) Proinflammatory T helper type 17 cells are effective B-cell helpers. Proc Natl Acad Sci 107:1429214297

Mohamed HEA, Afridi S, Khalil AT, Ali M, Zohra T, Akhtar R, Ikram A, Shinwari ZK, Maaza M (2020) Promising antiviral, antimicrobial and therapeutic properties of green nanoceria. Nanomedicine 15 : $467-488$

Nikitina E, Larionova I, Choinzonov E, Kzhyshkowska J (2018) Monocytes and macrophages as viral targets and reservoirs. Int J Mol Sci 19:2821

Ojo SA, Lateef A, Azeez MA, Oladejo SM, Akinwale AS, Asafa TB, Yekeen TA, Akinboro A, Oladipo IC, Gueguim-Kana EB (2016) Biomedical and catalytic applications of gold and silver-gold alloy nanoparticles biosynthesized using cell-free extract of Bacillus safensis LAU 13: antifungal, dye degradation, anti-coagulant and thrombolytic activities. IEEE Trans Nanobioscience 15:433-442

Organization WH (2020) Coronavirus disease 2019 (COVID-19): situation report, 72

Panda PK, Arul MN, Patel P, Verma SK, Luo W, Rubahn H-G, Mishra YK, Suar M, Ahuja R (2020) Structure-based drug designing and immunoinformatics approach for SARS-CoV-2. Sci Adv 6: eabb8097

Park H-J, Lee E-Y, Jung S, Ko HL, Lee S-M, Nam J-H (2017) Spike nanoparticle and recombinant adenovirus 5 vaccines induce specific antibodies against the Middle East respiratory syndrome coronavirus (MERS-CoV). Am Assoc Immnol

Pérez-Casares A, Cesar S, Brunet-Garcia L, Sanchez-de-Toledo J (2017) Echocardiographic evaluation of pericardial effusion and cardiac tamponade. Front Pediatr 5:79

Poeck H, Bscheider M, Gross O, Finger K, Roth S, Rebsamen M, Hannesschläger N, Schlee M, Rothenfusser S, Barchet W (2010) Recognition of RNA virus by RIG-I results in activation of CARD9 and inflammasome signaling for interleukin $1 \beta$ production. Nat Immunol 11:63-69

Rai PK, Usmani Z, Thakur VK, Gupta VK, Mishra YK (2020) Tackling COVID-19 pandemic through nanocoatings: confront and exactitude. Curr Opin Green Sustain Chem 3:100011

Scheerlinck J-PY, Greenwood DLV (2008) Virus-sized vaccine delivery systems. Drug Discov Today 13:882-887

Schneider-Ohrum K, Ross TM (2012) Virus-like particles for antigen delivery at mucosal surfaces. In: Kozlowski PA (ed) Mucosal vaccines: modern concepts, strategies, and challenges. Springer Berlin Heidelberg, Berlin, pp 53-73

Sekhon BS, Saluja V (2011) Nanovaccines-an overview. Int J Pharm Front Res 1:101-109

Sivakumar B (2020) Educational evaluation survey on corona virus 19 (an awareness)-South India. Stud Ind P1 Nam 40:228-234
Sportelli MC, Izzi M, Kukushkina EA, Hossain SI, Picca RA, Ditaranto N, Cioffi N (2020) Can nanotechnology and materials science help the fight against SARS-CoV-2? Nanomaterials 10:802

Storch GA (2000) Diagnostic Virology. Clin Infect Dis 31:739-751

Su S, Wong G, Shi W, Liu J, Lai AC, Zhou J, Liu W, Bi Y, Gao GF (2016) Epidemiology, genetic recombination, and pathogenesis of coronaviruses. Trends Microbiol 24:490-502

Takeuchi O, Akira S (2008) MDA5/RIG-I and virus recognition. Curr Opin Immunol 20:17-22

Thompson R (2020) Pandemic potential of 2019-nCoV. Lancet Infect Dis 20:280

Tran DN, Vu NN, Nhan T, Bich NTT, Quang ML, To NB, Le Van P, Dang VQ (2020) Silver nanoparticles as potential antiviral agents against African swine fever virus. Materials Research Express

Venugopal VK, Mahajan V, Rajan S, Agarwal VK, Rajan R, Syed S, Mahajan H (2020) A systematic meta-analysis of CT features of COVID-19: lessons from radiology. medRxiv

Verma A, Uzun O, Hu Y, Hu Y, Han H-S, Watson N, Chen S, Irvine DJ, Stellacci F (2008) Surface-structure-regulated cell-membrane penetration by monolayer-protected nanoparticles. Nat Mater 7:588-595

Vos LM, Bruning AH, Reitsma JB, Schuurman R, Riezebos-Brilman A, Hoepelman AI, Oosterheert JJ (2019) Rapid molecular tests for influenza, respiratory syncytial virus, and other respiratory viruses: a systematic review of diagnostic accuracy and clinical impact studies. Clin Infect Dis 69:1243-1253

Wong CW, Chan YS, Jeevanandam J, Pal K, Bechelany M, Abd Elkodous M, El-Sayyad GS (2020) Response surface methodology optimization of mono-dispersed $\mathrm{MgO}$ nanoparticles fabricated by ultrasonic-assisted sol-gel method for outstanding antimicrobial and antibiofilm activities. J Clust Sci 31:367-389

Wu J, Wu X, Zeng W, Guo D, Fang Z, Chen L, Huang H, Li C (2020) Chest CT findings in patients with coronavirus disease 2019 and its relationship with clinical features. Investig Radiol 55:257-261

Xu C, Zheng J, Wu A (2020) Antibacterial applications of TiO 2 nanoparticles. TiO2 nanoparticles, 105-132

Yang P, Wang X (2020) COVID-19: a new challenge for human beings. Cell Mol Immunol

Zhang H, Penninger JM, Li Y, Zhong N, Slutsky AS (2020a) Angiotensin-converting enzyme 2 (ACE2) as a SARS-CoV-2 receptor: molecular mechanisms and potential therapeutic target. Intensive Care Med:1-5

Zhang H, Penninger JM, Li Y, Zhong N, Slutsky AS (2020b) Angiotensin-converting enzyme 2 (ACE2) as a SARS-CoV-2 receptor: molecular mechanisms and potential therapeutic target. Intensive Care Med 46:586-590

Zheng Y-Y, Ma Y-T, Zhang J-Y, Xie X (2020) COVID-19 and the cardiovascular system. Nat Rev Cardiol 17:259-260

Zhou P, Yang XL, Wang XG, Hu B, Zhang L, Zhang W, Si HR, Zhu Y, Li B, Huang CL, Chen HD, Chen J, Luo Y, Guo H, Jiang RD, Liu MQ, Chen Y, Shen XR, Wang X, Zheng XS, Zhao K, Chen QJ, Deng F, Liu LL, Yan B, Zhan FX, Wang YY, Xiao GF, Shi ZL (2020) A pneumonia outbreak associated with a new coronavirus of probable bat origin. Nature 579:270-273

Zhu N, Zhang D, Wang W, Li X, Yang B, Song J, Zhao X, Huang B, Shi W, Lu R (2020) China novel coronavirus investigating and research team. A novel coronavirus from patients with pneumonia in China, 2019. N Engl J Med 382:727-733

Publisher's note Springer Nature remains neutral with regard to jurisdictional claims in published maps and institutional affiliations. 